\title{
Harvest Date, Cultivar, Orchard, and Tree Effects on Water Vapor Permeance in Apples
}

\author{
Kate M. Maguire and Nigel H. Banks \\ Centre for Postharvest and Refrigeration Research, Massey University, Private Bag 11 222, Palmerston \\ North, New Zealand
}

Alexander Lang
HortResearch, Palmerston North Research Centre, Private Bag 11 030, Palmerston North, New Zealand

Ian L. Gordon

Institute of Molecular Biosciences, Massey University, Private Bag 11 222, Palmerston North, New Zealand

AdDitional INDEX words. Malus sylvestris var. domestica, water loss, weight loss, cuticle

\begin{abstract}
Research quantified contributions to total variation in water vapor permeance from sources such as cultivar and harvest date in 'Braeburn', 'Pacific Rose', 'Granny Smith', and 'Cripps Pink' apples [Malus sylvestris (L.) Mill. var. domestica (Borkh.) Mansf.]. In a study on 'Braeburn' fruit from eight orchards in Central Otago, New Zealand, $>50 \%$ of the total variation in permeance was associated with harvest date. This variation was the result of a large increase in water vapor permeance from $16.6 \mathrm{to} 30.2(\mathrm{SE}=0.88, \mathrm{df}=192) \mathrm{nmol} \cdot \mathrm{s}^{-1} \cdot \mathrm{m}^{-2} \cdot \mathrm{Pa}^{-1}$ over the 8 week experimental harvest period. Fruit to fruit differences accounted for $22 \%$ of total variation in permeance. Interaction between harvest date and orchard effects explained $7 \%$ of the total variation, indicating that fruit from the different orchards responded in differing ways to advancing harvest date. Tree effects accounted for only $1 \%$ of the total variation. Weight loss from respiration [at $20{ }^{\circ} \mathrm{C}$ and $\approx 60 \%$ relative humidity $(\mathrm{RH})]$ comprised $3.04 \pm 0.11 \%$ of total weight loss, averaged across all harvest dates. In a second study of fruit of four apple cultivars, almost $30 \%$ of the total variation in water vapor permeance was associated with cultivar differences. Mean water vapor permeance for 'Braeburn', 'Pacific Rose', 'Granny Smith', and 'Cripps Pink' fruit was 44, 35,17 , and $20(\mathrm{SE}=4.3, \mathrm{df}=300) \mathrm{nmol} \cdot \mathrm{s}^{-1} \cdot \mathrm{m}^{-2} \cdot \mathrm{Pa}^{-1}$ respectively. Over $20 \%$ of the total variation was associated with harvest date and arose from a large increase in water vapor permeance from $21 \mathrm{nmol} \cdot \mathrm{s}^{-1} \cdot \mathrm{m}^{-2} \cdot \mathrm{Pa}^{-1}$ at first harvest to $46 \mathrm{nmol} \cdot \mathrm{s}^{-1} \cdot \mathrm{m}^{-}$ ${ }^{2} \cdot \mathrm{Pa}^{-1}(\mathrm{SE}=5.3, \mathrm{df}=200)$ at final harvest, 10 weeks later, on average across all four cultivars. There was large fruit to fruit variation in water vapor permeance accounting for $25 \%$ of the total variation in permeance values. Tree effects only accounted for $4 \%$ of the total variation. Water vapor permeance in 'Pacific Rose' ' and 'Braeburn' increased substantially with later harvest but values remained relatively constant for 'Granny Smith' and 'Cripps Pink'. A simple mathematical model was developed to predict weight loss from 'Braeburn' fruit. Based on these findings, it appears worthwhile to increase the stringency of measures to control weight loss in 'Braeburn' and 'Pacific Rose' apples, particularly those harvested late in the season.
\end{abstract}

Apples (Malus sylvestris var. domestica) lose weight through transpiration and respiration. Weight loss is an important contributor to development of high quality ripened fruit, because insufficient water loss during fruit ripening can lead to disorders such as mealiness (Hatfield and Knee, 1988; Johnson, 1976) and low temperature breakdown (Wills and Scott, 1972). On the other hand, excessive weight loss and its associated disorder, shrivel (visible wrinkling), causes losses in crop value. Hatfield and Knee (1988) reported that as little as 5\% loss in weight can cause shrivel in apples. Anecdotal evidence from the New Zealand apple industry suggests there are high levels of variability in the development of shrivel and levels of weight loss among apples within individual packages harvested during the 3 to 4 week commercial harvest period. This indicates variability in water vapor permeance of individual fruit.

In a constant environment, the effective permeance of the fruit surface to water vapor $\left(P_{\mathrm{H}_{2} \mathrm{O}}^{\prime} ; \mathrm{mol} \cdot \mathrm{s}^{-1} \cdot \mathrm{m}^{-2} \cdot \mathrm{Pa}^{-1}\right)$ can be calculated from rate of water loss $\left(r_{\mathrm{H}_{2} \mathrm{O}} ; \mathrm{mol} \cdot \mathrm{s}^{-1}\right)$ using the steady state solution of Fick's first law of diffusion (Nobel, 1991):

Received for publication 16 Dec. 1998. Accepted for publication 31 Aug. 1999. This paper is based on a portion of a $\mathrm{PhD}$ thesis submitted by K.M. Maguire. We express appreciation to ENZAFRUIT New Zealand (International) for funding this work and Arlene Bradley for fruit collection. The cost of publishing this paper was defrayed in part by the payment of page charges. Under postal regulations, this paper therefore must be hereby marked advertisement solely to indicate this fact.

$$
P_{\mathrm{H}_{2} \mathrm{O}}^{\prime}=r_{\mathrm{H}_{2} \mathrm{O}}^{\prime} / p_{\mathrm{H}_{2} \mathrm{O}} A
$$

provided $p_{\mathrm{H}_{2} \mathrm{O}}$ (the difference in partial pressure of water vapor between the environment and inside the fruit; $\mathrm{Pa}$ ) and $A$ (the surface area of the fruit; $\mathrm{m}^{2}$ ) are known.

$P_{\mathrm{H}_{2} \mathrm{O}}^{\prime}$ is a measure of the ease with which water vapor can escape from fruit. In Table 1, some published average values for $P_{\mathrm{H}_{2} \mathrm{O}}^{\prime}$ of apples have been converted to a common set of units using formulae published by Banks et al. (1995). The measured values of permeance range from $0.6 \mathrm{nmol} \cdot \mathrm{s}^{-1} \cdot \mathrm{m}^{-2} \cdot \mathrm{Pa}^{-1}$ for 'Granny Smith' fruit (Nobel, 1975) to $145.1 \mathrm{nmol} \cdot \mathrm{s}^{-1} \cdot \mathrm{m}^{-2} \cdot \mathrm{Pa}^{-1}$ for 'Russet' (Lentz and Rooke, 1964), a 240-fold range. Even within cultivars, there is great variation in published values; for 'Golden Delicious' fruit, the average values range from $16.6 \mathrm{nmol} \cdot \mathrm{s}^{-1} \cdot \mathrm{m}^{-2} \cdot \mathrm{Pa}^{-}$ ${ }^{1}$ (Pieniazek, 1943) to $70 \mathrm{nmol} \cdot \mathrm{s}^{-1} \cdot \mathrm{m}^{-2} \cdot \mathrm{Pa}^{-1}$ (Wells, 1962). The current work quantified contributions of respiration to total weight loss of 'Braeburn' fruit and variance in $P_{\mathrm{H}_{2} \mathrm{O}}^{\prime}$ in four cultivars of apples-'Braeburn', 'Pacific Rose', 'Granny Smith', and 'Cripps Pink' as affected by harvest date, orchard, and tree effects, to provide information that will facilitate management of weight loss in storage in the apple industry.

\section{Materials and Methods}

HARVEST DATE, ORCHARD, AND TREE EFFECTS ON WATER VAPOR PERMEANCE OF 'BRAEBURN' FrUIT. Six visually unblemished fruit 
Table 1. Average estimates of water vapor permeance for different cultivars of apples calculated from published data.

\begin{tabular}{|c|c|c|}
\hline $\begin{array}{r}\mathrm{P} \\
(\mathrm{nmo}\end{array}$ & $\begin{array}{l}\text { ermeance } \\
\left.1 \cdot \mathrm{s}^{-1} \cdot \mathrm{m}^{-2} \cdot \mathrm{Pa}^{-1}\right)\end{array}$ & Source \\
\hline Baldwin & 15 & Pieniazek (1943) \\
\hline Bancroft & 34 & Lentz and Rooke (1964) \\
\hline Cortland & 17 & Lentz and Rooke (1964) \\
\hline \multirow[t]{2}{*}{ Cox's Orange Pippin } & 43 & Smith (1933) \\
\hline & 31 & Johnson (1976) \\
\hline \multirow[t]{5}{*}{ Golden Delicious } & 47 & Kessler and Stoll (1953) \\
\hline & 37 & Pieniazek (1942a) \\
\hline & 17 & Pieniazek (1943) \\
\hline & 34 & Smock and Neuburt (1950) \\
\hline & 70 & Wells (1962) \\
\hline Granny Smith & 1 & Nobel (1975) \\
\hline Gravenstein & 2 & Nobel (1975) \\
\hline Grimes Golden & 63 & Wells (1962) \\
\hline \multirow[t]{3}{*}{ Jonathan } & 27 & Kessler and Stoll (1953) \\
\hline & 1 & Nobel (1975) \\
\hline & 32 & Wells (1962) \\
\hline \multirow[t]{3}{*}{ McIntosh } & 17 & Lentz and Rooke (1964) \\
\hline & 21 & Pieniazek (1942a) \\
\hline & 12 & Pieniazek (1943) \\
\hline Northern Spy & 18 & Lentz and Rooke (1964) \\
\hline \multirow[t]{2}{*}{ Red Delicious } & 36 & Lentz and Rooke (1964) \\
\hline & 9 & Chau et al. (1988) \\
\hline \multirow[t]{2}{*}{ Rhode Island Greening } & 33 & Lentz and Rooke (1964) \\
\hline & 16 & Pieniazek (1942a,b) \\
\hline Russet & 145 & Lentz and Rooke (1964) \\
\hline Sandow & 33 & Lentz and Rooke (1964) \\
\hline Yellow Transparent & 22 & Pieniazek (1943) \\
\hline
\end{tabular}

were randomly sampled from each of four trees from eight orchards in the Otago region, New Zealand on each of five harvest dates (a total of 960 fruit). The first harvest was 28 Mar. 1995; with subsequent harvests at 2 week intervals. $P_{\mathrm{H}_{2} \mathrm{O}}^{\prime}$ was calculated for each fruit using Eq. (1). Within $48 \mathrm{~h}$ of harvest, fruit were placed in an airflow of $\approx 3 \mathrm{~m} \cdot \mathrm{s}^{-1}$ and rate of weight loss from each fruit determined twice at each recording interval over a $16 \mathrm{~h}$ period using a balance to $0.001 \mathrm{~g}$ (model PM1206; Mettler Toledo, Switzerland). An average RH was determined by wet and dry bulb temperature readings (thermistor probes $\mathrm{CM}$ type, $\mathrm{U}$ bead, $\pm 0.2^{\circ} \mathrm{C}$; Grant Instruments, Cambridge, United Kingdom). Skin temperature was logged (Squirrel model 1206, Grant Instruments) using thermistor probes (FF type, $\mathrm{U}$ bead, $\pm 0.2{ }^{\circ} \mathrm{C}$; Grant Instruments) inserted under the skins of several fruit. Average values for $\Delta p_{\mathrm{H}_{2} \mathrm{O}}$ were calculated using psychrometric relationships (Monteith and Unsworth, 1990; Tetens, 1930). Surface area was estimated using an equation developed by Clayton et al. (1995).

Respiration rates were determined by measuring the change in partial pressure of $\mathrm{CO}_{2}$ within $1200 \mathrm{~mL}$ opaque containers over $60 \mathrm{~min}$ at $20^{\circ} \mathrm{C}$. Fruit were equilibrated to $20^{\circ} \mathrm{C}$ and $60 \% \mathrm{RH}$ for $24 \mathrm{~h}$ before measurements. Rates of weight loss were corrected for respiration to provide estimates of rates of water loss.

CONTRIBUTION OF RESPIRATION TO TOTAL WEIGHT LOSS OF 'BRAEBURN' FRUit. The percentage contribution to total weight loss by respiration was modelled using an equation developed by Cheng et al. (1998), which relates specific respiration rate $\left(r_{\mathrm{CO}_{2}}\right.$; $\left.\mathrm{mol} \cdot \mathrm{kg}^{-1} \cdot \mathrm{s}^{-1}\right)$ of 'Braeburn' apples to temperature $\left(\mathrm{T} ;{ }^{\circ} \mathrm{C}\right)$ :
$r_{\mathrm{CO}_{2}}=\left(20.8+(2.3 T)+\left(0.131 T^{2}\right)\right) \times 10^{-9}$

Eq. [2]

Rate of water loss was estimated using

$r_{\mathrm{H}_{2} \mathrm{O}}^{\prime}=P_{\mathrm{H}_{2} \mathrm{O}}^{\prime} A\left[p_{\mathrm{H}_{2} \mathrm{O}}^{\text {sat }}(T)(1-\mathrm{RH} / 100)\right]$

where $p_{\mathrm{H}_{2} \mathrm{O}}^{\text {sat }}(T)$ is the saturated water vapor pressure at air temperature $\left(\mathrm{T} ;{ }^{\circ} \mathrm{C}\right)$ and $\mathrm{RH}$ is the relative humidity of the air. We assumed the fruit had a water vapor permeance of 30 $\mathrm{nmol} \cdot \mathrm{s}^{-1} \cdot \mathrm{m}^{-2} \cdot \mathrm{Pa}^{-1}$, an average value of water vapor permeance for 'Braeburn' apples (N.H. Banks, unpublished data), an initial weight $(M)$ of $0.16 \mathrm{~kg}$, a surface area $(A)$ of $0.016 \mathrm{~m}^{2}$, and a surface temperature the same as air temperature. Total weight loss $\left(r_{\text {mass }}^{\prime}\right.$; $\left.\mathrm{kg} \cdot \mathrm{s}^{-1}\right)$ was modelled as:

$r_{\text {mass }}^{\prime}=\left(0.012 r_{\mathrm{CO}_{2}} M\right)+\left(0.018 r_{\mathrm{H}_{2} \mathrm{O}}^{\prime}\right)$

assuming a respiratory quotient of unity and taking account of the molecular weights of carbon and water $(0.012$ and $0.018 \mathrm{~kg}$ $\mathrm{mol}^{-1}$, respectively). Respiration as a percentage of total weight loss $(r r \%)$ was

$r r \%=\left(0.012 r_{\mathrm{CO}_{2}} M\right) / r_{\text {mass }}^{\prime} \times 100 \% \quad$ Eq. [5]

HARVEST DATE, CULTIVAR AND TREE EFFECTS ON WATER VAPOR PERMEANCE OF APPLE FRUIT. Five visually unblemished fruit were harvested from each of 10 'Braeburn', 'Pacific Rose' , 'Cripps Pink', and 'Granny Smith' trees at the Fruit Crops Unit research orchard at Massey University, Palmerston North, New Zealand, on each of six harvest dates (a total of 1200 fruit). Variation associated with maturity was minimized by selecting fruit for the study on the basis of uniform background color at the first harvest (19 Mar. 1996). Subsequent harvests were made at 2-week intervals. $P_{\mathrm{H}_{2} \mathrm{O}}^{\prime}$ was calculated for each fruit using Eq. [1] using estimates of rates of weight loss, without correction for respiration, made within $48 \mathrm{~h}$ of harvest.

HARVEST DATE EFFECTS ON WATER VAPOR PERMEANCE OF APPLE FRUIT. Five visually unblemished fruit were harvested from each of ten 'Braeburn' trees from the Fruit Crops Unit research orchard at Massey University, Palmerston North, New Zealand, on each of five harvests (a total of 250 fruit). Variation associated with maturity was minimized by selecting fruit for the study on the basis of uniform background color at the first harvest (31 Mar. 1997). Subsequent harvests were made at 2 -week intervals; the interval between first and final harvests was 8 weeks. Rates of weight loss and respiration were measured within $48 \mathrm{~h}$ of harvest as described above. $P_{\mathrm{H}_{2} \mathrm{O}}^{\prime}$ was calculated for each fruit using estimates of total weight loss corrected for respiration.

Data were analyzed using a cross-nested model in the GLM procedure of SAS (SAS Institute Inc., 1988). Contributions of variance components were calculated from mean squares corrected for model effects.

\section{Results}

HARVEST DATE, ORCHARD, AND TREE EFFECTS ON WATER VAPOR PERMEANCE OF 'BRAEBURN' FrUIT. Values for $P_{\mathrm{H}_{2} \mathrm{O}}^{\prime}$ from the entire sample were highly variable. There was a 5 -fold difference between the lowest and highest measured water vapor permeance. Fruit to fruit variation explained $22 \%$ of the total variance. A further $65 \%$ of the variation was associated with harvest date. Across all orchards, permeance increased from an average of 16.6 at first harvest to 30.2 $(\mathrm{SE}=0.88, \mathrm{df}=192) \mathrm{nmol} \cdot \mathrm{s}^{-1} \cdot \mathrm{m}^{-2} \cdot \mathrm{Pa}^{-1}$ at final harvest 8 weeks later. A further $4 \%$ of total variation in permeance was associated with orchard effects. Interaction of harvest and orchard effects ac- 


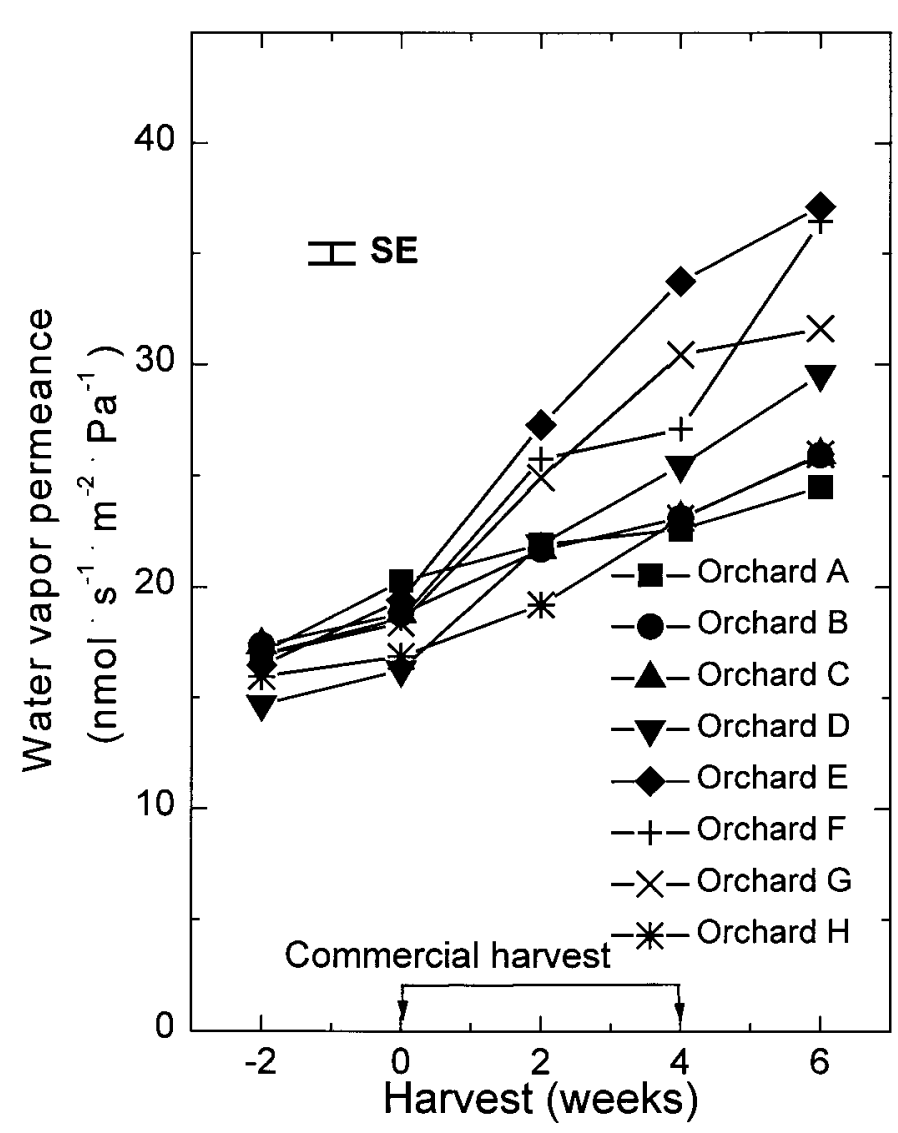

Fig. 1. Water vapor permeance of fruit from eight orchards harvested at different times relative to start of the commercial harvest season $(0$ weeks; $\mathrm{SE}=0.93$, df $=24)$.

counted for $7 \%$ of total variation. $P_{\mathrm{H}_{2} \mathrm{O}}^{\prime}$ of fruit from the different orchards had increased at final harvest to 1.5 to 2.3 -fold the values at first harvest (Fig. 1). Tree effects explained a further $1 \%$ of the total variation. Only the final $1 \%$ was associated with measurement error.

CONTRIBUTION OF RESPIRATION TO TOTAL WEIGHT LOSS OF 'BRAEBURN' FRUIT. Across all orchards, respiration rate at $20^{\circ} \mathrm{C}$ increased from 93.7 to $178.2(\mathrm{sE}=7.16, \mathrm{df}=192) \mathrm{nmol} \cdot \mathrm{kg}^{-1} \cdot \mathrm{s}^{-1}$ over the 8-week period between initial and final harvests. Weight loss due to respiration, as a percentage of total weight loss, remained approximately constant at $3.04 \pm 0.11 \%$ across all harvest dates. Percentage weight loss estimated at $20^{\circ} \mathrm{C}$ and $60 \%$ $\mathrm{RH}$ from the model was similar at $2.7 \%$ (Fig. 2). Estimated temperature effects on respiration as a percentage of total weight loss were negligible; $\mathrm{RH}$ was the main influencing variable (Fig. 2).

HARVEST DATE, CULTIVAR, AND TREE EFFECTS ON WATER VAPOR PERMEANCE OF APPLE FRUIT. Values for $P_{\mathrm{H}_{2} \mathrm{O}}^{\prime}$ from the entire sample were extremely variable, with fruit to fruit variation and measurement error explaining $25 \%$ of the total variance. A further $30 \%$ of total variation in permeance was associated with cultivar. Mean values of $P_{\mathrm{H}_{2} \mathrm{O}}^{\prime}$ for 'Braeburn' (43.8 $\left.\mathrm{nmol} \cdot \mathrm{s}^{-1} \cdot \mathrm{m}^{-2} \cdot \mathrm{Pa}^{-1} ; \mathrm{sE}=4.3, \mathrm{df}=300\right)$, and 'Pacific Rose' ' $(35.4$ $\left.\mathrm{nmol} \cdot \mathrm{s}^{-1} \cdot \mathrm{m}^{-2} \cdot \mathrm{Pa}^{-1}\right)$ were nearly twice those of 'Granny Smith' and 'Cripps Pink' (17.3 and $20.5 \mathrm{nmol} \cdot \mathrm{s}^{-1} \cdot \mathrm{m}^{-2} \cdot \mathrm{Pa}^{-1}$, respectively). A further $21 \%$ of the variation was associated with harvest date. Across all cultivars, permeance increased from an average of 21.4 at first harvest to $46.4(\mathrm{sE}=5.3, \mathrm{df}=200) \mathrm{nmol} \cdot \mathrm{s}^{-1} \cdot \mathrm{m}^{-2} \cdot \mathrm{Pa}^{-1}$ at final harvest 10 weeks later. The final $22 \%$ of total variation was due to an interaction of harvest and cultivar effects. $P_{\mathrm{H}_{2} \mathrm{O}}^{\prime}$ of 'Braeburn' increased nearly 4-fold and that of 'Pacific Rose' doubled between first and final harvests while values for 'Granny Smith' and Cripps Pink' remained stable (Fig. 3).

HARVEST DATE EFFECTS ON WATER VAPOR PERMEANCE OF APPLE FRUIT. Averaged across fruit from all trees, permeance of 'Braeburn' apples increased almost 2-fold from an average of 11.5 at first harvest to $29.4 \mathrm{nmol} \cdot \mathrm{s}^{-1} \cdot \mathrm{m}^{-2} \cdot \mathrm{Pa}^{-1}(\mathrm{SE}=1.03, \mathrm{df}=50)$ at final harvest (8 weeks later).

\section{Discussion}

The increase in water vapor permeance of 'Braeburn' fruit with later harvest date was consistent over all 3 years of this work in different regions, orchards, and trees. Values of water vapor permeance at the beginning of the season, and the extent of the increase with later harvested fruit were different between the 2 years that fruit were sampled from the research orchard. Greater initial values and the larger increases seen in the 1996 seasons possibly explains the much higher incidence of shrivel observed in the New Zealand pipfruit industry in 1996 (Richardson personal communication, 1998) compared with the following year. Regardless of origin or season, it seems that 'Braeburn' fruit harvested late in the season are more prone to shrivel in storage than early harvested 'Braeburn' fruit.

The first study showed that there was only a small error associated with repeated measurements, indicating that the method used was reliable, and that only one set of measurements per fruit would be required to characterise $P_{\mathrm{H}_{2} \mathrm{O}}^{\prime}$. The error term in analysis of variance of permeance data could be mainly attributed to natural variation in fruit. Variation among fruit from different trees was also small. This indicates that water vapor permeance is a fruit characteristic and that influences of whole tree physiology and genetic variation within a cultivar were minimal. While samples should be drawn to reflect an entire population under study, there appears to be no need to develop sampling strategies to systematically collect information from large numbers of different trees.

'Braeburn' and 'Pacific Rose' fruit had higher $P_{\mathrm{H}_{2} \mathrm{O}}^{\prime}$ than 'Granny Smith' and 'Cripp's Pink' fruit, particularly in later harvests. 'Braeburn' and 'Pacific Rose' ' fruit would therefore be more prone to shrivel in storage than 'Granny Smith' and 'Cripp's Pink' fruit, especially if they were picked late in the harvest

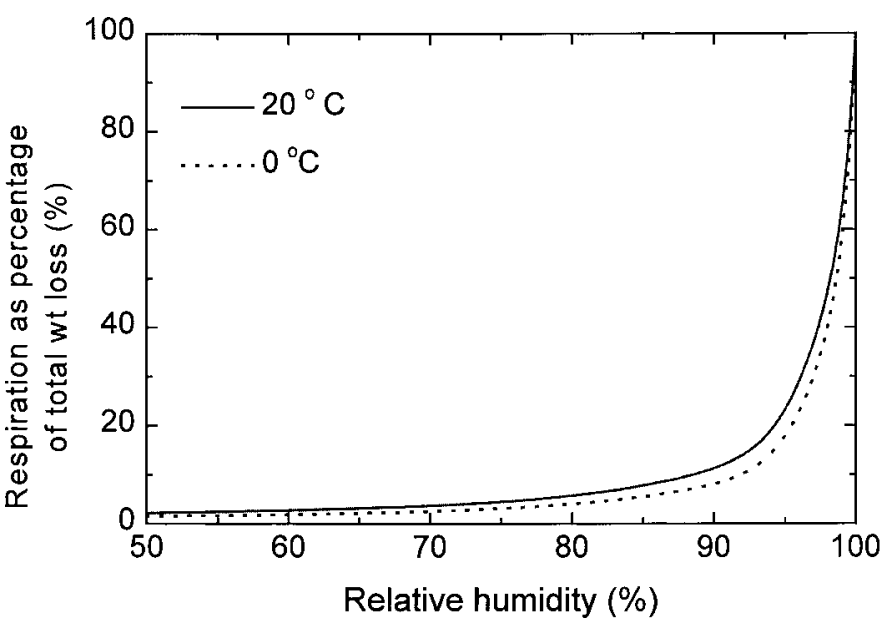

Fig. 2. Predicted relationship between respiration as percentage of total weight loss and RH for 'Braeburn' apples using the model described in Eqs. 1-5. 


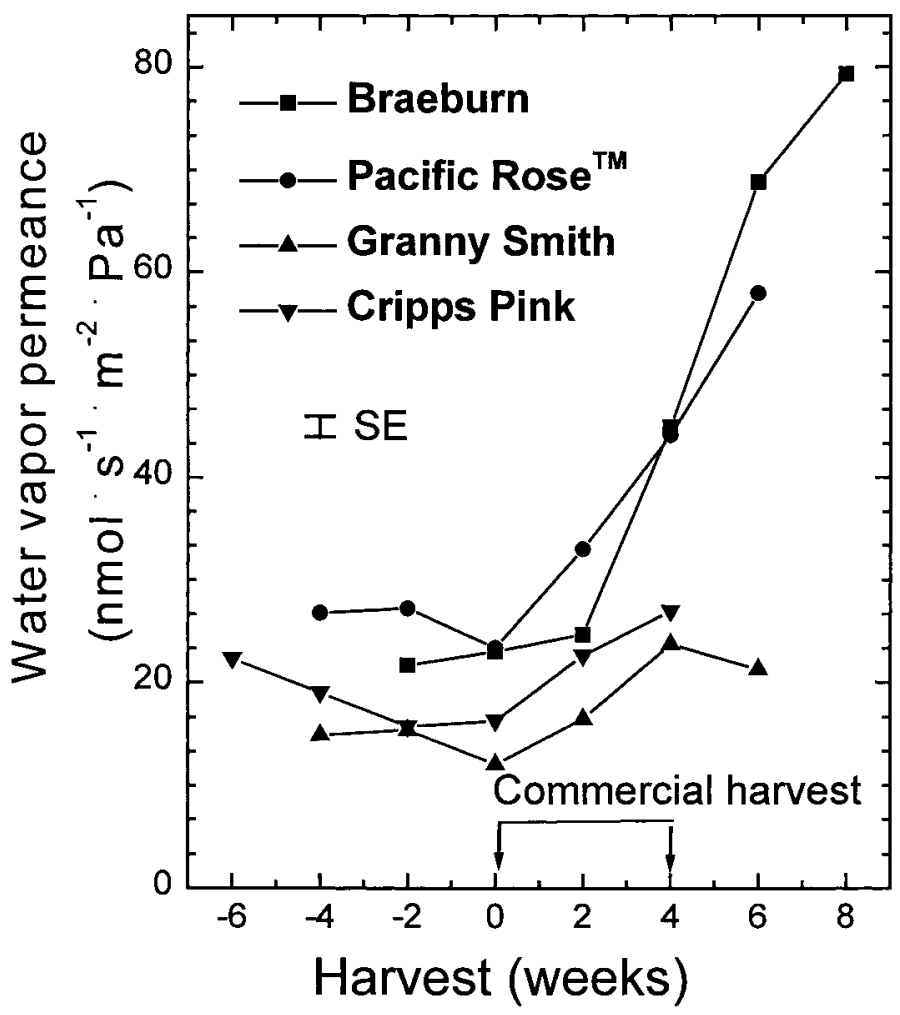

Fig. 3. Water vapor permeance of fruit from 'Braeburn', 'Pacific Rose', 'Cripps Pink', and 'Granny Smith' trees harvested at different times relative to start of the commercial harvest season for each cultivar ( 0 weeks; $\mathrm{sE}=2.03, \mathrm{df}=50$ ).

season. Contrasting trends with harvest date among cultivars have also been observed in other studies. Pieniazek (1943), for example, recorded that $P_{\mathrm{H}_{2} \mathrm{O}}^{\prime}$ increased in 'Golden Delicious', 'McIntosh', 'Yellow Transparent', and 'Rhode Island Greening' fruit with later harvest whereas permeance of 'Baldwin' fruit remained constant.

Variation in permeance among cultivars is presumably related to variation in the physical and chemical properties of the outer layers of the fruit such as lenticels (Pieniazek, 1944), cuticle thickness (Kamp, 1930), the presence of microcracking (Meyer, 1944) and the amount and type of cuticular waxes (Riederer and Schneider, 1990). Increases in permeance with later harvest date and differences among the orchard responses could result from the influence of a number of inherent growth and environmental factors on these properties. It would be interesting to explore the causes of the increase in $P_{\mathrm{H}_{2} \mathrm{O}}^{\prime}$ with later harvest in some cultivars.

Given the relationship between permeance and rate of water loss in a given environment, fruit from earlier harvests would, on average, be less prone to shrivel than their late-harvested counterparts. However, there would still be early-harvested fruit that would have shrivelled sooner than others, due to variation in properties of the cuticle that developed during growth. This would be a likely source of the variation in incidence of shrivel found within commercial packs.

Our model (Eqs. 1-5) estimated that the percentage weight loss through respiration that would occur in commercial air storage of New Zealand 'Braeburn' apples $\left(0^{\circ} \mathrm{C}\right.$ and $\left.90 \% \mathrm{RH}\right)$ accounted for only $7 \%$ of total weight loss. On this basis, strategies for reducing total weight loss during storage should be directed at reducing water loss, as this was the dominant component.
The model can also approximate the effect of delays in precooling or the effect of high humidity storage on total weight loss of a fruit. As it is based on individual fruit rather than packages, it does not account for the fact that neither cooling nor equilibration of humidity are instantaneous processes. The latter would be affected by water sinks in the cartons such as packaging material buffering the increase in RH from moisture loss of the fruit (Eagleton and Marcondes, 1994; Merts, 1996). The model also ignores effects of the boundary layer within which there is no turbulent mixing. The thickness of the boundary layer is inversely related to air velocity (Nobel, 1975) and packaging materials (trays and liners) interfere with free air movement, influencing the thickness of the boundary layer, and hence the true driving force for water loss.

Water vapor permeance of the fruit was fixed at 30 $\mathrm{nmol} \cdot \mathrm{s}^{-1} \cdot \mathrm{m}^{-2} \cdot \mathrm{Pa}^{-1}$ for each model run at all levels of RH. Smith (1930) found that water vapor permeance declines after harvest to reach a steady level. Several researchers (Fockens and Meffert, 1972; Lentz and Rooke, 1964; Sastry et al., 1978; Smith, 1933) have reported that estimates of $P_{\mathrm{H}_{2} \mathrm{O}}^{\prime}$ increase with decreasing $\Delta p_{\mathrm{H}_{2} \mathrm{O}}$. In addition, we assumed that respiration rate of the fruit was constant during the 8 week period and not dependent on RH. In reality, duration and magnitude of a climacteric would be affected by the temperature at which the fruit is held (Kidd and West, 1930).

Clearly, accurate definition of response of the system to all of

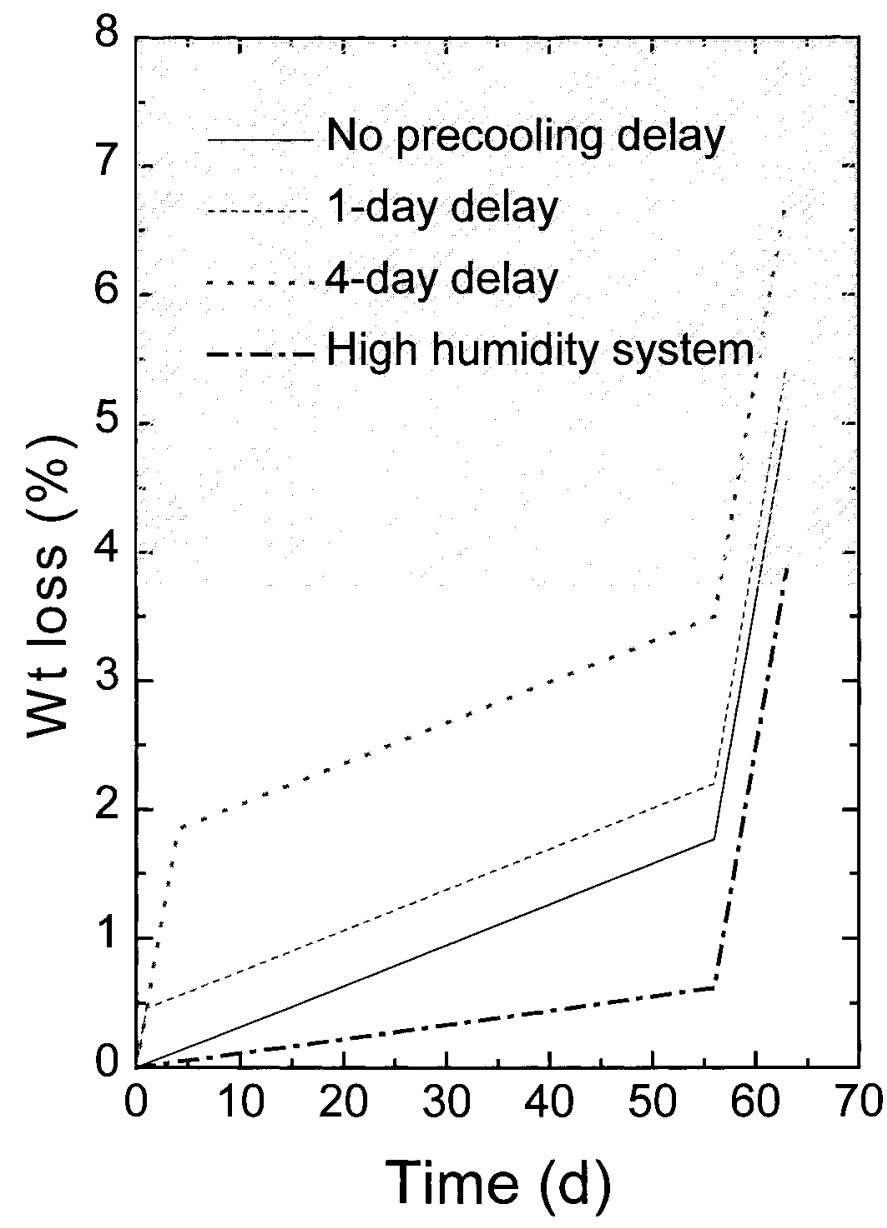

Fig. 4. Predicted weight loss from a 'Braeburn' fruit in several different postharvest scenarios using the model described in Eqs. 1-5. The shaded region represents levels of weight loss likely to induce shrivel. 
these factors would require considerable additional work. Inclusion of these more refined characterizations into the model should enhance the accuracy of its predictions provided that values for all of the input variables were known. Nevertheless, the simple unvalidated model presented herein has enabled some useful first predictions of relative importance of transpiration and respiration to be made.

Fruit with a permeance of $30 \mathrm{nmol} \cdot \mathrm{s}^{-1} \cdot \mathrm{m}^{-2} \cdot \mathrm{Pa}^{-1}$ were predicted to lose about $5 \%$ of initial weight if precooled instantly and then stored at $0{ }^{\circ} \mathrm{C}$ and $90 \% \mathrm{RH}$ for 8 weeks, then given a shelf life period of $7 \mathrm{~d}$ at $20^{\circ} \mathrm{C}$ and $60 \% \mathrm{RH}$ (Fig. 4). Delaying precooling for $1 \mathrm{~d}$ in an environment at $20{ }^{\circ} \mathrm{C}$ and $60 \% \mathrm{RH}$ would have increased the total weight loss to $5.4 \%$. If this delay was extended to $4 \mathrm{~d}$, total weight loss was predicted to rise to $6.7 \%$ (Fig. 4 ). The amount of weight loss sufficient to cause shrivel in individual fruit ranges from $3.5 \%$ to $10 \%$ (N.H.Banks, unpublished data); any delay in precooling could thus result in some fruit developing shrivel. If these fruit were in a system that achieved a RH of 97\% during storage, the weight loss would be $3.9 \%$ following 8 weeks storage at $0{ }^{\circ} \mathrm{C}$ and a $7 \mathrm{~d}$ shelf life at $20^{\circ} \mathrm{C}$ and $60 \% \mathrm{RH}$ after removal from packaging. Clearly, potential to reduce weight loss is enhanced considerably under such conditions. Polyliners can create such humidities but also reduce substantially the efficiency of precooling (Merts 1996), largely countering benefits that the increased humidity would offer for reducing weight loss and enhancing the likelihood for fruit becoming mealy (Hatfield and Knee, 1988).

In conclusion, this study indicates that 'Pacific Rose' and 'Braeburn' apples, particularly those harvested late in the picking season, are highly prone to shrivel because of their high permeance to water vapor. These fruit should be passed through the marketing chain quickly, with optimal temperature and humidity control, to minimize the occurrence of shrivel.

Although strategies for management of weight loss in storage can be developed from the information reported herein, there is still a large amount of fruit to fruit variation which remains unexplained. Further work quantifying the influence of soluble cuticular lipids and physical properties of the cuticle such as thickness and presence of microcracking on water vapor permeance may help to define ways in which the production environment could be managed to reduce susceptibility to weight loss after harvest.

\section{Literature Cited}

Banks, N.H., D.J. Cleland, A.C. Cameron, R.M. Beaudry, and A.A. Kader. 1995. Proposal for a rationalised system of units for postharvest research in gas exchange. HortScience 30:1129-1131.

Chau, K.V., R.A. Romero, C.D. Baird, and J.J. Gaffney. 1988. Transpiration coefficients for certain fruits and vegetables. Trans. Amer. Soc. Heat Refrigeration Air Conditioning Eng. 94:553-562.

Cheng, Q., N.H. Banks, S.E. Nicholson, A.M. Kingsley, and B.R. MacKay. 1998. Effects of temperature on gas exchange of 'Braeburn' apples. N.Z. J. Crop Hort. Sci. 26:299-306.

Clayton, M., N.D. Amos, N.H. Banks, and R.H. Morton. 1995. Estimation of apple fruit surface area. N. Z. J. Crop Hort. Sci. 23:345-349.

Eagleton, D.G. and J.A. Marcondes. 1994. Moisture-sorption isotherms for paper-based components of transport packaging for fresh produce. Tech. Assn. Pulp Paper Ind. J. 77:75-81.

Fockens, F.H. and H.F.Th. Meffert. 1972. Biophysical properties of horticultural products related to loss of moisture during cooling down. J. Sci. Food Agr. 23:285-298.

Hatfield, S.G.S. and M. Knee. 1988. Effects of water loss on apple in storage. Intl. J. Food Sci. Technol. 23:575-583.

Johnson, D.S. 1976. Influence of water loss on the storage quality of apples. Chem. Ind. 18:1044-1046.

Kamp, H. 1930. Untersuchungen uber kutikularbau und kutikulare transpiration von blattern. Jahrb. Wiss. Bot. 72:403-465.

Kessler, H. and K. Stoll. 1953. Versuchsergebnisse bei der kaltlagerung von apfelsorten. Landw. Jb. Schweiz.1157-1184.

Kidd, F. and C. West. 1930. Physiology of fruit I.: Changes in the respiratory activity of apples during their senescence at different temperatures. Proc. Royal Soc. London, Series B Biol. Sci. 106:93109.

Lentz, C.P. and E.A. Rooke. 1964. Rates of moisture loss of apples under refrigerated storage conditions. Food Technol. 18:119-121.

Merts, I. 1996. Mathematical modelling of modified atmosphere packaging systems for apples. PhD diss., Massey Univ., Palmerston North, New Zealand.

Meyer, A. 1944. A study of the skin structure of golden delicious apples. Proc. Amer. Soc. Hort. Sci. 45:105-110.

Monteith, J.L. and M.H. Unsworth. 1990. Principles of environmental physics. 2nd ed. Edward Arnold, New York.

Nobel, P.S. 1975. Effective thickness and resistance of the air boundary layer adjacent to spherical plant parts. J. Expt. Bot. 26:120-130.

Nobel, P.S. 1991. Physicochemical and environmental plant physiology. Academic Press, New York.

Pieniazek, S.A. 1942a. A study of factors influencing the rate of transpiration of apple fruits. PhD diss., Cornell Univ., Ithaca, N.Y.

Pieniazek, S.A. 1942b. External factors affecting water loss from apples in cold storage. Refrigeration Eng. 44:171.

Pieniazek, S.A. 1943. Maturity of apple fruits in relation to the rate of transpiration. Proc. Amer. Soc. Hort. Sci. 42:231-237.

Pieniazek, S.A. 1944. Physical characters of the skin in relation to apple fruit transpiration. Plant Physiol. 19:529-536.

Riederer, M. and G. Schneider. 1990. The effect of the environment on the permeability and composition of citrus leaf cuticles. II. Composition of soluble cuticular lipids and correlation with transport properties. Planta 180:154-165.

SAS Institute Inc. 1988. SAS/STAT user's guide. release 6.03 ed. SAS Inst., Cary, N.C.

Sastry, S.K., C.D. Baird, and D.D. Buffington. 1978. Transpiration rates of certain fruits and vegetables. Trans. Amer. Soc. Heat Refrigeration Air Conditioning Eng. 84:237-255.

Smith, W.H. 1930. Loss of water from fruit. Great Brit. Dept. Sci. Ind. Res. Rept. of the Food Investigation Board.

Smith, W.H. 1933. Evaporation from apples in relation to temperature and atmospheric humidity. Ann. Appl. Biol. 20:220-235.

Smock, R.M. and A.M. Neuburt. 1950. Apples and apple products. Interscience, New York.

Tetens, O. 1930. Uber einige meterologische begriffe. Zeitschrift Geophysik 6:297-309.

Wells, A.W. 1962. Effects of storage temperature and humidity on loss of weight by fruit., Mkgt. Res. Rpt. no. 539. Agr. Mkgt. Serv., U.S. Dept. Agr.

Wills, R.B.H., and K.J. Scott 1972. Methods of increasing water loss from apples to reduce low temperature breakdown. J. Hort. Sci. 47:349-355. 